\title{
Effect of jejunal resection in rats subjected to partial hepatectomy
}

\author{
Efeito da ressecção jejunal em ratos submetidos a hepatectomia parcial
}

\begin{abstract}
Aline Rochelle Filgueira Dantas, Candice Alves Esmeraldo, Luisa Dutra de Medeiros, Ítalo Medeiros Azevedo, Amália Cínthia Meneses Rêgo, Vítor Brasil Medeiros, Vanessa de Fátima Lima Paiva Medeiros, Irami Araújo-Filho, Aldo Cunha Medeiros

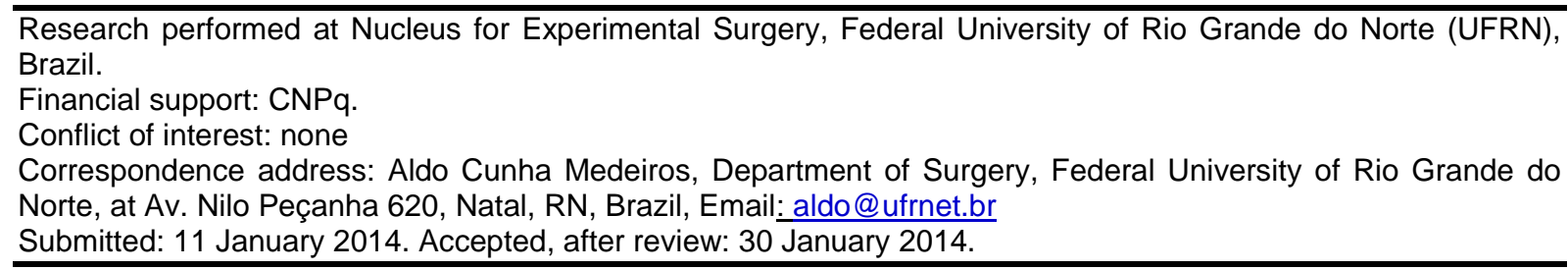

\begin{abstract}
Objective: Extensive resection of the bowel, associated with hepatectomy, has been increasingly performed, so that to date there is controversy regarding the participation of proximal intestine on the liver regeneration. The study tested the hypothesis that the regulation of liver regeneration may be done separately by the jejunum. Methods: Eighteen Wistar rats were distributed into 3 groups, each with 6 rats: group 1, jejunectomy+hepatectomy; group 2, hepatectomy; group 3, sham. The rats were weighed before surgery and immediately before euthanasia that occurred on the 6th postoperative day, when their livers were weighted as well. Alanineaminotransferase (ALT), aspartate-aminotransferase (AST and alkaline phosphatase (ALP were measured. The calculation of liver regeneration was based on the liver weight / body mass ratio at the time of euthanasia and immediate postoperative period. Results: In group hepatectomy+jejunectomy ALT, AST and ALP were $182.4 \pm 23.7,59.3 \pm 3.2$ and $258.6 \pm 44.2$ respectively, significantly higher than in the hepatectomy group, whose values were $124.2 \pm 14.3 ; 43.7 \pm 3.5$ and $166.3 \pm 8.3$ respectively $(p<0.001)$. Liver regeneration in the hepatectomy group was $93.18 \pm$ $12.87 \%$, statistically higher $(p<0.001)$ than in jejunectomy+hepatectomy group $(53.84 \pm 11.32 \%)$. Conclusion: These data support the evidence that the jejunectomy negatively influenced liver regeneration.
\end{abstract}

Key words: Liver regeneration. Hepatectomy. Intestinal resection. Jejunum. Rats.

\section{RESUMO}

Objetivo: Ressecções extensas do intestino, associadas à hepatectomias, quer por lesões traumáticas, quer por doenças malignas, têm sido cada vez mais frequentemente realizadas, de modo que até o presente há controvérsias a respeito da participação de segmentos do intestino na regeneração do fígado. Testar a hipótese segundo a qual a regulação da regeneração hepática pode ser exercida pelo jejuno separadamente, podendo esse segmento intestinal ser efetivo no processo. Metodologia: Foi realizado um estudo experimental controlado e randomizado, utilizando 18 ratos Wistar. Os animais foram alocados em 3 grupos, cada um com 6 ratos: grupo 1, ressecção do jejuno + hepatectomia; 
grupo 2, hepatectomia e grupo 3, sham (simulação). Os ratos foram pesados antes da cirurgia e imediatamente antes do sacrifício que ocorreu no 6을 dia de observação, em que também foi realizado a pesagem do fígado, além de dosagens séricas de enzimas hepáticas. O cálculo da regeneração hepática foi baseado na razão massa hepática/massacorporal no momento da eutanásia e pós-operatório imediato. Resultados: No grupo hepatectomia + ressecção jejunal a TGP, TGO e FA foram 182,4 $\pm 23,7 ; 59,3 \pm 3,2$ e $258,6 \pm 44,2$ respectivamente, significativamente mais elevadas do que no grupo hepatectomia, com valores $124,2 \pm 14,3 ; 43,7 \pm 3,5$ e $166,3 \pm 8,3$, respectivamente $(p<0,001)$. A regeneração hepática no grupo submetido à hepatectomia $(93,18 \pm 12,87 \%)$ foi estatisticamente maior $(p<0,001)$ que nos ratos do grupo hepatectomia + ressecção jejunal $(53,84 \pm 11,32 \%)$. Conclusão: Há, portanto, indícios de que alguns mecanismos derivados do jejuno e provenientes da circulação portal contribuem para a regulação da relação fígado/massa corpórea, favorecendo o processo de regeneração hepática.

Descritores: Regeneração hepática. Hepatectomia parcial. Jejunum. Ressecção intestinal.

\section{INTRODUCTION}

Studies with hepatocellular carcinoma suggest that there may be more mechanisms which contribute to regulating the growth of hepatocytes during liver regeneration than currently known ${ }^{1}$. Current knowledge has been useful for understanding liver regeneration as a set of homeostatic phenomena. Liver regeneration after partial (2/3) hepatectomy in rodents has become a useful model for studying the regenerative growth of the organ. The model is based on two important aspects. Firstly, the removal of resected tissue is not associated with severe necrosis. Second, the resected liver tissue are capable of "clean" resection due to multilobular structure of rat liver. Thus, the regeneration of the residual lobes is mediated by processes targeted to the liver tissue and usually does not occur acute necrosis or inflammation ${ }^{2}$.

After $2 / 3$ hepatic resection in rats, each residual liver lobe retains its blood supply via the hepatic artery and portal vein branches. Whereas the quantity of arterial blood irrigating each lobe remains essentially the same, the relative proportion and amount of blood supplying increases three times to each lobe. Thus, the flow of blood through the portal unit by hepatocytes or liver mass increases three times after resection. Theoretically, it would be a positive factor for accelerating regeneration ${ }^{2}$.

After extensive resection of the small bowel, the remaining intestine undergoes a compensatory mitogenic response called adaptation. This wellcharacterized reaction results in increased length and caliber of the remaining intestine ${ }^{3.4}$. Microscopically, the intestinal mucosa becomes thicker with increasing in both villus height and crypts depth. In addition to these morphological and functional alterations, an increase in the secretion of digestive enzymes and absorption and transport activity of íons occur ${ }^{5}$. Although the mechanisms and/or mediators in 
intestinal adaptation are not well understood, there is strong evidence to suggest that humoral factors, pancreaticobiliares secretions and luminal nutrients are all important $^{6,7}$. The epidermal growth factor, and its intestinal receptor may be present in the genesis of this process ${ }^{8}$. This appears to be involved in mediating adaptive liver regeneration after partial hepatectomy parcial ${ }^{9-11}$. Although the combination of intestinal resection with hepatectomy is being studied in some models to assess hepatic regeneration ${ }^{12-14}$, little is known about the intestinal adaptation when considering this association. Indeed, several intestinal factors have been implicated to play a role in liver regeneration, and include transforming growth factor, epidermal growth factor, interleukin - 6 ( IL - 6) and tumor necrosis factor- $\alpha$ (TNF- $\alpha)^{15,16}$. Regarding to IL-6, experimental studies have demonstrated that serum levels were increased but without significant changes after small bowel resection of $70 \%$ in rats ${ }^{17}$. In several animal models it has been shown bacterial translocation to mesenteric lymph nodes, liver, and spleen after major bowel resection ${ }^{18-20}$. The mechanism for this is currently unknown, but appears to be secondary to changes in intestinal permeability ${ }^{21}$. Increased bacterial translocation from the gut has been postulated associated with major hepatic resection ${ }^{22}$. Similarly, endotoxin have been implicated as deleterious effects on liver regeneration after hepatectomy ${ }^{23}$. Indeed, it was previously demonstrated that extensive hepatectomy combined with small bowel resection are associated with increased levels of endotoxin in plasma in both portal and systemic blood. Thus, it is possible that attenuated liver regeneration seen after extensive small bowel resection must be due to endotoxins and bacteria derived from the intestine. Reduced and low liver regeneration after extensive small bowel resection cell proliferation have been demonstrated, not knowing if there is a predominance of the jejunum or ileum involvement of the gut in that process ${ }^{24}$.

Therefore, there is evidence that some mechanisms derived from the intestine and the portal circulation contribute to the regulation of liver/body mass ratio ${ }^{2}$. It is shown that $50 \%$ resection of the proximal intestine is associated with a significant reduction in hepatic total mass ${ }^{25}$. There is controversy about the role of the small intestine in regulating the recovery of liver mass after injury, with some studies suggesting that the gut is an essential source of some humoral factor in liver regeneration after partial hepatectomy ${ }^{26-28}$. Other studies indicate that the small intestine may not be necessary for this regenerative response ${ }^{29,30}$. Huang et al demonstrated that there is a factor (known FXR) which affects the absorption of bile acids, which in turn can regulate the liver mass and its recovery after injuries, giving support for the role of the small intestine in regulating the hepatic mass ${ }^{31}$.

Based on these data, the aim of this protocol is to test the hypothesis that the regulation of liver regeneration may be done by the jejunum. An experimental model of jejunectomy was used to examine the involvement of proximal intestine in the liver mass/ body mass ratio, and liver function tests. 


\section{METHODS}

Wistar rats were housed in individual polypropylene cages with 12-hour light/dark cycles, with ad libitum access to water and food. Animals previously undergone a period of 7 days acclimation on the laboratory. One day before the operations, the animals were kept on liquid diet. The rats were divided into 3 groups, each with 6 rats: Group 1, resection of the jejunectomy+hepatectomy, group 2, hepatectomy; and group 3, sham. Rats were anesthetized with intramuscular ketamine $50 \mathrm{mg} / \mathrm{kg}$, and xylazine $10 \mathrm{mg} / \mathrm{kg}$, and were operated under aseptic technique. Postoperative pain was controlled analgesia (i.m. meperidine $10 \mathrm{mg} / \mathrm{kg}$, for the first 3 days). The protocol was approved by the Institutional Ethics Committee on Animal Research. We followed all the precepts of ethics studies in animals provided by Brazilian guidelines.

A $40 \mathrm{~cm}$ jejunectomy was performed at $3 \mathrm{~cm}$ distal to Treitz angle. Intestinal continuity was restored by end-to-end anastomosis in single layer with interrupted sutures, using 6-0 polypropylene by using the surgical microscope DFV ( São Paulo, Brazil ), 10x magnification. The sham operation consisted of laparotomy and manipulation of the jejunum with atraumatic clamp. The partial hepatectomy consisted of resection of the left and median lobes, corresponding to 2/3 of the liver mass. The abdominal wound was sutured with nylon 4-0. After the operations, the animals received only water by the first 24 hours, followed by rodent solid diet until the day of euthanasia. The animals were weighed before the operation and on the 5th postoperative day.

\section{SERUM MEASUREMENTS}

Serum from whole blood collected by cardiac puncture on the 5th postoperative day was obtained by centrifugation at $1500 \mathrm{rpm}$ for 10 minutes and stored at $-30^{\circ} \mathrm{C}$ until dosages. Serum ALT, AST, alkaline phosphatase (ALP) were measured in all animals through autoanalyzer (Weiner BT Lab Plus 3000).

\section{LIVER REGENERATION MEASUREMENT}

Firstly we calculated the liver mass/body mass ratio (LMBMR). After the observation period the rats were weighed $(B)$, the liver completely removed and weighed on a precision balance $(A)$. The data obtained were expressed as the percentage ratio of $A$ to $B$ multiplied by 100 . The LMBMR was calculated by the formula:

$$
L M B M R=\frac{\text { Liver mass }}{\text { Body mass }} x 100
$$


The preoperative liver total weight was calculated using the average LMBMR of sham group at the time of euthanasia. Changes in LMBMR on animals of groups 1 , 2 and 3 were considered as degree of liver regeneration. The liver regeneration (LR) was calculated by the formula:

$$
\% L R=\frac{\text { LMBMReuthanasia }- \text { LMBMRpostop }}{\text { LMBMRpostop }} \times 100
$$

$\% \mathrm{LR}=$ Percentage of liver regeneration;

LMBMReuthanasia = Liver mass/body mass ration at euthanasia;

LMBMRpostop = Liver mass/body mass ration in the immediate postoperative period (immediately after hepatectomy).

\section{STATISTICAL ANALYSIS}

The data were analyzed using SPSS 18.0 (Chicago, IL, USA). To verify that the results obtained had statistically significant differences the following parametric tests were used: 1) Student's $t$ - independent samples to compare between two groups, 2) analysis of variance (ANOVA) - to compare more than two groups, 3) Tukey test - used when the ANOVA showed significance, 4) Non-parametric Kruskal Wallis test - to check for differences between the three groups, when there was no homogeneity of variances, and 5) Dunnett test - when the Kruskal Wallis test showed significance; this test was used to determine in which groups the differences were statistically significant. For all tests the differences were significant when $p<0.05$.

\section{RESULTS}

In the hepatectomy+jejunectomy group, ALT, AST and ALP were 182.4 \pm 23.7 , $59.3 \pm 3.2$ and $258.6 \pm 44.2$ respectively, which were significantly higher than in the hepatectomy group, whose values were $124,2 \pm 14.3,43.7 \pm 3.5$ and $166.3 \pm 8.3$, respectively $(p<0.001)$. These data are summarized in Table 1.

Table 1 - Tests of liver function

\begin{tabular}{|c|c|c|c|c|}
\hline Enzimas (U/L) & $\begin{array}{c}\text { Hepatectomy+ } \\
\text { jejunectomy }\end{array}$ & Hepatectomy & Sham & p-valor \\
\hline $\mathrm{ALT}^{3}$ & $182.4 \pm 23.7^{*}$ & $124.2 \pm 14.3^{*}$ & $43.2 \pm 4.2^{*}$ & $<0.001^{(1)}$ \\
\hline $\mathrm{AST}^{3}$ & $59.3 \pm 3.2^{\S}$ & $43.7 \pm 3.5^{\S}$ & $48.2 \pm 3.3^{\S}$ & $<0.001^{(1)}$ \\
\hline $\mathrm{ALP}^{4}$ & $258.6 \pm 44.2^{\bullet}$ & $166.3 \pm 8.3^{\star}$ & $142.3 \pm 15.8^{\star}$ & $0.001^{2}$ \\
\hline \multicolumn{5}{|c|}{$\begin{array}{l}\text { Mean } \pm \text { Standard deviation } \\
1 \text { - p-value from ANOVA. } \\
2 \text { - p-value from non-parametric Kruskal-Wallis test. } \\
3 \text { - Values in the same line - followed by the same symbol mean significant diferences - Tukey test. } \\
4 \text { - Values in the same line - followed by the same symbol mean significant diferences -Dunnett test. }\end{array}$} \\
\hline
\end{tabular}


Table 2 - Hepatic regeneration

\begin{tabular}{c|ccc}
\hline \multirow{2}{*}{ Organ } & \multicolumn{2}{|c}{ HEPATIC REGENERATION (\%) } & \multirow{2}{*}{ p-value $^{(1)}$} \\
\cline { 2 - 3 } & Jejunectomy+hepatectomy & Hepatectomy & \\
\hline Liver & $53.84 \pm 11.32$ & $93.18 \pm 12.87$ & $<0.001$ \\
\hline Mean \pm Standard deviation & & \\
1. P-value using the Student t test for independent samples. &
\end{tabular}

Liver regeneration of the Sham group was calculated, however, showed an average 0.0 . This was due to the fact that liver regeneration calculations have been made considering the measures of the livers of animals from this group. Using the weights of the livers of the sham group, were found that RMHMC had the average of 0.0318 . Therefore, it was found that on average, each animal, before treatment had a RMHMC $3.18 \%$, i.e. the weight of the liver of the Wistar rats, at the same conditions of age and sex, represents $3.18 \%$ of their body weight. The data in Table 2 show that liver regeneration in the hepatectomy group $(93.18 \pm 12.87)$ was significantly higher $(p<0.001)$ than in the hepatectomy+jejunectomy group $(53.84 \pm 11.32)$.

\section{DISCUSSION}

The findings of our study were consistent with the data of Nelson et $\mathrm{al}^{25}$, who demonstrated that massive resection of the small intestine associated with partial hepatectomy impairs the liver's ability to regenerate. The proliferation index showed up attenuated. The data support the important role of the intestinal mucosa for the regulation of hepatic regeneration. According to Nelson et $\mathrm{al}^{25}$, it is likely that the small intestine is a significant source of hepatotrophic factors that are present in portal blood perfusing the liver. Thus, massive intestinal removal may have reduced the ability to sustain a trophic effect on the native liver and in the regeneration process. Moreover, when rats were subjected only to massive small bowel resection there was a significant decrease in the wet weight of the liver, confirming the hypothesis of participation of small intestine in liver trophism ${ }^{25}$. However there is still the possibility that the removal of intestinal signaling pathways give rise to an delay, but not suppression of the regeneration ${ }^{32}$. In contrast to the above findings, and the present work, Sasanuma et $\mathrm{al}^{33}$ reported decreased liver function after synchronous liver and colon resection in rats. However, this study showed that despite the greater regenerative process, liver function and weight gain in the animals were restricted. The researchers' explanation for such restrictions was likely higher degree of endotoxemia in postoperative course.

According to the results of Cui-Ping $\mathrm{Xu}$, et $\mathrm{al}^{26}$, the mechanism of endotoxemia in hepatectomized rats may be the intestinal mucosal barrier injury and decrease of the absolute number and depression of the functional status of Kupffer cells (KCs). It was shown that the damage to the intestinal mucosa barrier causes transient endotoxemia when the function of $\mathrm{KCs}$ is depressed, resulting in sustained 
endotoxemia. It is suggested that the main reason for the sustained increase in the level of endotoxins post-hepatectomy may be the depression of the function and number of KCs.

To assess the cellular response of liver parenchyma in all three groups we used serum ALT, AST and alkaline phosphatase. We observe that the values of the investigated enzymes showed a statistically significant increase in the hepatectomy+ jejunectomy group rats compared to the group undergoing liver resection only, being more pronounced the elevation of ALT and alkaline phosphatase compared to AST. These data demonstrate the greatest degree of injury to the remnant liver in group hepatectomy+jejunectomy over group hepatectomy, since transaminases are secreted into the interstitium and circulation after the occurrence of injury to hepatocytes ${ }^{34}$.

To analyze the degree of liver regeneration in the present study we used a calculation based on the ratio of liver mass/body mass. Our results confirmed that the rats submitted to jejunectomy+hepatectomy showed a regeneration rate of the remnant liver significantly lower compared to rats which underwent only partial hepatectomy. These results are consistent with our previous findings. We demonstrated that the ileum resection negatively influenced the liver regeneration, liver mass and liver function in the late postoperative period ${ }^{35}$.

\section{CONCLUSION}

These data support the evidence that the jejunectomy negatively influenced liver regeneration.

\section{REFERENCES}

1. Keng VW, Villanueva A, Chiang DY, Dupuy AJ, Ryan BJ, Matise I, Silverstein KA, Sarver A, Starr TK, Akagi K, Tessarollo L, Collier LS, Powers S, Lowe SW, Jenkins NA, Copeland NG, Llovet JM, Largaespada DA. A conditional transposon-based insertional mutagenesis screen for genes associated with mouse hepatocellular carcinoma. Nature Biotechnol. 2009, 27:264-74.

2. Michalopoulos GK: Liver regeneration. J Cell Physiol 2007, 213:286-300.

3. Williamson RC. Intestinal adaptation. Structural, functional and cytokinetic changes. N Engl J Med. 1978;298:1393-402.

4. Williamson RC. Intestinal adaptation. Mechanisms of control. N Engl J Med. 1978;298:1444-50.

5. Falcone RA, Jr., Shin CE, Stern LE, et al. Differential expression of ileal $\mathrm{Na} / \mathrm{H}$ exchanger isoforms after enterectomy. J Surg Res. 1999;86:192-7. 
6. Williamson RC, Bauer FL, Ross JS, et al. Proximal enterectomy stimulates distal hyperplasia more than bypass or pancreaticobiliary diversion. Gastroenterology. 1978;74:16-23.

7. Feldman EJ, Dowling $\mathrm{RH}$, McNaughton $\mathrm{J}$, et al. Effects of oral versus intravenous nutrition on intestinal adaptation after small bowel resection in the dog. Gastroenterology. 1976;70:712-9.

8. Stern LE, Erwin CR, O'Brien DP, et al. Epidermal growth factor is critical for intestinal adaptation following small bowel resection. Microsc Res Tech. 2000;51:138-48.

9. Jones DE, Jr., Tran-Patterson R, Cui DM, et al. Epidermal growth factor secreted from the salivary gland is necessary for liver regeneration. Am J Physiol. 1995;268:G872-8.

10. Lambotte L, Saliez A, Triest S, et al. Effect of sialoadenectomy and epidermal growth factor administration on liver regeneration after partial hepatectomy. Hepatology. 1997;25:607-12.

11. Rasmussen TN, Jorgensen PE, Almdal T, et al. Stimulatory effect of epidermal growth factor on liver regeneration after partial hepatectomy in rats. Scand $\mathrm{J}$ Gastroenterol. 1992;27:372-4.

12. Poirier RA, Cahow CE. Role of the small intestine in liver regeneration. Am Surg. 1974;40:555-7.

13. Miyazaki $\mathrm{M}$, Kohda $\mathrm{S}$, Itoh $\mathrm{H}$, et al. Inhibition of hepatic regeneration after $70 \%$ partial hepatectomy by simultaneous resection of the bowel in rats. Eur Surg Res. 1995;27:396-405.

14. Fisher $B$, Szuch $P$, Levine $M$, et al. The intestine as a source of a portal blood factor responsible for liver regeneration. Surg Gynecol Obstet. 1973;137:210-4.

15. Michalopoulos GK, DeFrances MC. Liver regeneration. Science. 1997;276:606.

16. Fausto N. Liver regeneration. J Hepatol. 2000;32:19-31.

17. Lo HC, Tsai FA, Lin SC, et al. Systemic and local secretions of cytokines and nitric oxide in massive bowel resected rats with or without small bowel segment reversal. Cytokine. 2001;14:112-20.

18. Schimpl G, Feierl G, Linni K, et al. Bacterial translocation in short bowel syndrome in rats. Eur J Pediatr Surg. 1999;9:224-7.

19. Eizaguirre I, Aldazabal P, Barrena MJ, et al. Bacterial translocation is favored by the preservation of the ileocecal valve in experimental short bowel with total parenteral nutrition. Eur J Pediatr Surg. 1999;9:220-3.

20. Eizaguirre I, Aldazabal P, Barrena MJ, et al. Effect of growth hormone, epidermal growth factor, and insulin on bacterial translocation in experimental short bowel syndrome. J Pediatr Surg. 2000;35:692-5.

21. O'Brien DP, Nelson LA, Stern LE, et al. Epithelial permeability is not increased in rats following small bowel resection. J Surg Res. 2001;97:65-70.

22. Wang $\mathrm{XD}$, Parsson $\mathrm{H}$, Andersson $\mathrm{R}$, et al. Bacterial translocation, intestinal ultrastructure and cell membrane permeability early after major liver resection in the rat. Br J Surg. 1994;81:579-84. 
23. Mochida S, Ogata I, Hirata K, et al. Provocation of massive hepatic necrosis by endotoxin after partial hepatectomy in rats. Gastroenterology. 1990;99:771-7.

24. Miyazaki $\mathrm{M}$, Kohda $\mathrm{S}$, Itoh $\mathrm{H}$, et al. Inhibition of hepatic regeneration after $70 \%$ partial hepatectomy by simultaneous resection of the bowel in rats. Eur Surg Res. 1995;27:396-405.

25. Nelson LA, O'Brien DP, Kemp CJ, Williams JL, Dunke-Jacobs E, Erwin CR, Warner BW. Intestinal and hepatic response to combined partial hepatectomy and small bowel resection in mice. Am J Surg. 2002;183:435-40.

26. Xu CP, Liu J, Liu JC, Han DW, Zhang Y, Zhao YC. Dynamic changes and mechanism of intestinal endotoxemia in partially hepatectomized rats. World $\mathrm{J}$ Gastroenterol. 2007;13:3592-7.

27. Takada N, Ogita K, Taguchi T, Masumoto K, Suita S. The effect of a valine-rich diet on intestinal adaptation to massive small bowel resection in the rat. Transplant Proc. 2006;38:1830-5.

28. Jeschke MG, Bolder U, Finnerty CC, Przkora R, Müller U, Maihöfer R, Thompson JC, Wolf SE, Herndon DN. The effect of hepatocyte growth factor on gut mucosal apoptosis and proliferation, and cellular mediators after severe trauma. Surgery. 2005;138:482-9.

29. Iyer KR, Horslen S, Torres C, Vanderhoof JA, Langnas AN. Functional liver recovery parallels autologous gut salvage in short bowel syndrome. J Pediatr Surg. 2004;39:340-4.

30. Atici AE, Kaya $Y$, Coskun T, Aral E, Var A. Intestinal ischemia-reperfusion impairs liver regeneration after partial hepatectomy in rats. Hepatogastroenterology. 2003;50:661-5.

31. Huang W, Ma K, Zhang J, Qatanani M, Cuvillier J, Liu J, Dong B, Huang X, Moore DD. Nuclear receptor-dependent bile acid signaling is required for normal liver regeneration. Science. 2006;312:233-6.

32. Michalopoulos GK (2010) Liver regeneration after partial hepatectomy: critical analysis of mechanistic dilemmas. Am J Pathol 176: 2-13.

33. Sasanuma H, Mortensen FV, Knudsen AR, Funch-Jensen P, Okada M, Nagai $H$, Yasuda $Y$. Increased liver regeneration rate and decreased liver function after synchronous liver and colon resection in rats. Ann Surg Innov Res. 2009;3:16.

34. Mangus RS, O'Connor MG, Tector AJ, Lim JD, Vianna RM. Use of the aspartate aminotransferase to platelet ratio index to follow liver fibrosis progression in infants with short gut. J Pediatr Surg. 2010;45:1266-73.

35. Medeiros A. C, Brígido A. R. D, Silva S. M, Brito V. R, Rocha K. B. F, Oliveira C. N. The ileum as a determinant organ of the functional liver cell mass in rats. Acta Cir Bras. 2013; 28:210-15. 